\title{
Research and Practice in Revising Talent Training Programme in Local Agriculture Higher Educational Institutes
}

\section{-Based on the Case of Jilin Agriculture University}

Chunyan $\mathrm{Wu}^{1, \mathrm{a}}$,Yanhua $\mathrm{Yu}^{1, \mathrm{a}}$,Dongming Zhang ${ }^{1, \mathrm{a}}$, Chenjun Shen ${ }^{1, \mathrm{a}}$

1 Academic Affair Office, Jilin Agricultural University, Changchun, Jilin, 130118

a183904267@qq.com

Keywords: Local Agriculture Higher Educational Institutes; Talent Training Programme, Revision

\begin{abstract}
Talent training programme is the foundation based on which higher educational institute trains its talents, organises its teaching and learning plans and arranges individual studies for its students. Based on the revised working practice on 2014 talent training programme of Jilin Agriculture University, this paper will analyse the problems existing in the current talent training programme in the university. In addition, this paper will also discuss the confirmation of the guidance of talent training programme, construction of curriculum system, basic curriculum reform and etc., aiming at providing theoretical basis and practice experience for local agriculture colleges and universities during their process of major construction and reform, improving teaching quality and connotation construction.
\end{abstract}

\section{Introduction}

Talent training programme refers to a detailed plan designed for promoting the students to acquire scientific and cultural knowledge and skill in a systematic manner, form their morality and build a healthy body in accordance to training objectives, standards and students actual situation. Talent training programme is the foundation based on which higher educational institute trains its talents, organises its teaching and learning plans and arranges individual studies for its students. Based on the the revised working practice on 2014 talent training programme of Jilin Agriculture University, this paper will discuss the confirmation of the guidance of talent training programme, construction of curriculum system, basic curriculum reform and etc.

\section{The undergraduate major evaluation, this paper will explore into the problems existing in the current talent training programme}

In order to better understand the problems existing in the curriculum design and teaching time arrangement etc. in Jilin Agriculture University, this paper has analysed related problems in talent training programme for Class 2011 and 2012 based on the undergraduate major evaluation work of Jilin Agriculture University from 2011 to 2013. After organising and analysing questionnaires, the author has found out the following problems existing in the current talent training programme:

With long teaching hours and too many credits to earn, students have little spare time to dispose

According to the 2010 talent training programme, the average in-class hour for students is 2435 hours, ranging from 2598 hours and 2306 hours, with 292 hours of discrepancy. While for students in some engineering specialties, they might be required study for over 2600 hours. In terms of the average credit required to be earned by students in different majors, that of agricultural, science and engineering majors stands at 191 and for literature, management and legislative majors at 189. In every academic term, students are required to take 8 to 9 courses, and the actual class hours for each week reach at 30 hours, which demonstrates that students have little spare time at their disposal. 


\section{Curriculum design is dispersed, some of the courses are unnecessary and unscientifically structured}

There are a rather large number of classes in every major, with an average of 54 . In addition, the curriculum design is dispersed, overlapped and even repeated, with $38 \%$ students thinking that the content of some classes overlapped. Besides, there is a lack of links and connection between or among different disciplines, which means that curriculum design is unscientific and unsystematic and cannot fulfil the goal of talent training.

\section{The practice process features little significance and is not systematic}

According to the 2007-2011 experimental framework, 69\% experiment projects were updated, and there were $34 \%$ new experimental classes; 55\% of the content in placement framework was renewed and $44 \%$ of new placement content was added. Even though there are a large portion of content updated and added both in practice and teaching, and the number of class and length of in-class hours both meet the requirement of the government, there is still a lack of structured and systematic design between each link. There are altogether 42 separated designed experiment classes in the university, accounting for only $1.6 \%$ of the total courses. What is even worse, most experiment classes are dependent on theory courses, featuring little comprehensive and innovative content. Besides, since those classes have no independent academic performance evaluation system, they still need to be arranged and set separately.

\section{Relying on the practice of school-running to scientifically revision}

Since local colleges and universities should shoulder the responsibility to promote the economic development in local area, the revision of their talent training programme also requires to satisfy the need for social development so that the standard for talent cultivation can continuously be improved. According to the advantages and characteristics of Jilin Agriculture University's school-running process, this revision is guided by National Medium and Long-term Educational Reform and Development Planning Outline (2010-2020). The revision work aspires to explore into diversified talent training modes, improve students comprehensive capability, personality and psychological traits, promote the harmonious development of student's knowledge, capability and quality. Talent training programme is targeted atcultivating academic, application-oriented and interdisciplinary talents who have solid knowledge foundation, broadened horizon, comprehensive quality and innovative capability.” Based on this requirement, the design and overall requirement for revision are as follows:

The objective of talent training programme and curriculum design should reflect the school-running and major characteristics of the university. While designing its curriculum and major, Jilin Agriculture University is required to refer to the introduction to different majors in Directory of Undergraduate Majors for Regular Institutions for Higher Education (2012), combine the positioning of their school-running characteristics and determine the objective and process for talent training. In addition, it is also suggested to further integrate majors with similar characteristics, scientifically construct and optimise their curriculum system so that the advantages of each major can be highlighted and they can satisfy the need for social and economic development and development in higher education industry.

Reducing the total class hour and lowering credit requirement, so that the pressure of students can be alleviated. Based on the current talent training programme, the university need to further reduce in-class time and lower credit requirements for students. At the same time, the university is also suggested to integrate similar courses to avoid class repetition and unnecessary classes, strengthen the construction of key courses so that the curriculum can be designed to be structured and systematic. 


\section{Strictly standardising revision process to ensure the successful development of all revision work}

Within each faculty, a talent training programme revision seminar was organised based on each major. The meeting has invited all parties involved in talent training programme including directors within the faculty, teachers in specialised courses and basic courses, academic affair management staff, representatives from undergraduate students and from enterprises, public institutions and research institutions. During the meeting, those parties have thoroughly discussed the design of every links involved in talent training programme, based on which a first draft for talent training programme was made.

Based on the undergraduate major evaluation work of Jilin Agriculture university, the revision and argumentation of its talent training programme is also added to the evaluation process. After having a profound understanding about the university's school-running characteristics and construction situation, the experts within the industry and in higher education teaching management discussed the objectives of professional talent training, key curriculum design, course design and the practice process, providing an overall guidance for the revision of talent training programme.

Through exploring a multi-level and multi-link talent training programme evaluation mechanism, Jilin Agriculture University worked out an evaluation pattern following the process of "teachers of specialised course-major directer - faculty - evaluation experts - and academic affair office”. The strict implementation of the 5 level evaluation process can ensure the preciseness and science of the revision work of talent training programme.

\section{Implementing the reform of basic course and promoting the optimisation of basic courses}

In order to ensure the teaching quality after the adjustment of class hour in basic courses, and based on sufficient research and analysis on the problems existing in current curriculum design and construction and the reason for occurring such problems, the university implemented the "Jilin Agriculture University Basic Course Teaching Reform Project”. Through various effective measures, the university pinpointed the positioning of basic courses, innovative teaching pattern and method, and reformed its evaluation system. These measures satisfied students' need for diversified and individualised study, optimised the teaching system in basic course, and provided strong support for its talent training programme after the effective implementation of revision work.

The university organised each teaching unit to discuss the problems existing in their curriculum design, and to analyse the reasons leading to such problems. In addition, a leadership team responsible for basic course teaching reform project was also formed to organised and coordinate the reform in basic courses. In addition, the team has conducted research on the current situation of basic courses within the university, intending to have a profound knowledge on the condition and problems existing in basic courses, based on with a research report was produced.

Choosing and sending teachers in basic courses to research and study in other prestigious Chinese universities and colleges. At the same time, the university is also suggested to organise activity to promote the communication and connection between teachers in basic courses and in specialised courses, because by doing so the teachers in basic courses can understand the requirement of specialised course from basic course, and thus improve basic courses' role in supporting talent cultivation.

Improving teaching method, laying attention to the comprehensive reform on teaching method and ways of evaluation. The university can adopt flexible and diversified teaching method to improve students' interests in learning. Besides, it is also necessary to offer students with more opportunities to demonstrate their talents, increase the training in capabilities. Jilin Agriculture University is also encouraged to have a diversified examination system in which the cultivation of students' comprehensive capability can be made possible through optimising the evaluation of their study process.

Strengthening and perfecting the construction of teaching staff in basic courses based on the features of different courses, and establishing a group working mechanism. It is advised for the 
university to put more effort in the cultivation on young teachers, promote the communication and discussion of teaching among teachers. In order to effectively improve young teachers' teaching capability and level, it will be better to include both senior, experienced and young teachers in a group so that they can learn from each other, and the senior and experience teachers can pass on their experience, lead and help the younger ones. The university also need to create more opportunities for teachers in basic courses to pursue further study in other universities. As this can help them get informed of the most advanced information in the sector and accelerate the self development of teachers, and the improvement in teaching quality.

Improving the teaching environment and condition for basic course. Jilin Agriculture University is suggested to demonstrate more support for the construction of teaching staff dedicated to basic courses, providing them with various opportunities for further study and training, especially abroad and investing more money in basic course improvement.

\section{Conclusion}

Steady implementation of plan, and demonstration of advantages and characteristics in school-running in various aspects .After two years of revision, an undergraduate talent training programme for the Jilin Agriculture University with specific training objectives, distinctive specialised training and scientific curriculum design has come into being. Through comparison, it can be concluded that the revised talent training programme are different in terms of the provision of total class hour, credit requirement etc., and the revised programme features the following characteristics:

A more scientific and accurate target positioning. The objective of the revised talent training programme are more in line with the school-running characteristics and practice of Jilin Agriculture University. In the process of plan revision, the university organised 2 discussion on disciplinary and major school-running characteristics within each major, in which the requirement of improving talent training quality proposed by Ministry of Education and outlined in the strategy of "establishing Jilin into a higher education-oriented province" are taken into consideration. Through discussions, the characteristics for major school-running and school-running with different emphasises and targets are proposed.

Total class hour and credit requirements are further reduced and lowered. By doing so, students are provided with more time to dispose their spare time. To be more specific, the average class time is reduced by 181 hours; average credit requirement is decreases by 15.3 points; class time for basic courses reduce by 106 hours while practice hour increase by 5.6\% in terms of its proportion.

Curriculum structure is further optimised. The promotion between basic and specialised courses, key courses and general courses, compulsory and elective courses, theory and practice are all redesigned according to the requirement of talent training objectively. In addition, the limit in elective course within faculties is also broken, which provides more opportunities for the future academic development for students.

\section{Acknowledgement:}

Research and Practice on Curriculum Optimisation in Local Agriculture Universities under the Context of Higher Education Reform, project relating to The Twelfth Five Year Planning Project for Education Science in Jilin Province (No. ZD15053)

\section{Reference}

[1] Liu W Q; Zhang X Q. Research on Training Model for Application Oriented Animal Medical Professionals in Local Comprehensive University[J].Journal of Liaocheng University, 2016, 29(1):97-101

[2] Mu Y L.The Thinking on the Curriculum Reform of General Universities in the Process of Transformation[J].China Higher Education Research,,2014,9:84-91. 
[3] Verspoor L S. Pathways to Change. Improving the Quality of Education in Developing Countries [M]. Washington. DC: The World Bank, 1989: 133. 